\title{
Hepatic copper-and zinc-binding proteins in ruminants
}

\section{2. * Relationship between $\mathrm{Cu}$ and $\mathrm{Zn}$ concentrations and the occurrence of a metallothionein-like fraction}

\author{
By I. BREMNER AND R. B. MARSHALL† \\ Rowett Research Institute, Bucksburn, Aberdeen, $A B 2$ gSB \\ (Received 14 September 1973 - Accepted 26 February 1974)
}

\begin{abstract}
I. A metal-binding fraction with a molecular weight of about 12000 in calf and sheep liver has been characterized as a metallothionein-like protein.

2. The combined concentrations of copper and zinc in the fraction (as $\mu \mathrm{g} / \mathrm{g}$ liver) are a direct function of liver $\mathrm{Zn}$ concentration.

3. The relative proportions of $\mathrm{Cu}$ and $\mathrm{Zn}$ in the fraction are dependent on the $\mathrm{Cu}: \mathrm{Zn}$ ratio in the liver.

4. These findings may be relevant to the mutual interaction between $\mathrm{Cu}$ and $\mathrm{Zn}$.
\end{abstract}

In the previous paper (Bremner \& Marshall, I974) the effects of variations in copper and zinc status of ruminants on the distribution of the metals among soluble hepatic proteins were described. Three fractions $(\mathrm{I}-3)$, with approximate molecular weights of $\geqslant 75000,35000$ and 12000 , were isolated by gel filtration on Sephadex G-75 but none of these was fully characterized. The distributions of the $\mathrm{Cu}$ and $\mathrm{Zn}$ were closely related as, for example, $\mathrm{Zn}$ was absent from, or present in only low concentration in fraction 3 in high-Cu as well as in $\mathrm{Zn}$-deficient livers. Variable amounts of $\mathrm{Cu}$ occurred in this fraction, which is identified in this paper as a metallothionein-like protein. The total amount of $\mathrm{Cu}$ and $\mathrm{Zn}$ present in fraction 3 has been found to be a function of liver $\mathrm{Zn}$ concentration.

\section{EXPERIMENTAL}

Analytical methods. Details of the livers and their fractionation on Sephadex G-75 and some analytical methods were described in the previous paper (Bremner \& Marshall, 1974). Solutions were concentrated by ultrafiltration under nitrogen in a Diaflo cell, using UM2 filters (Amicon Ltd, High Wycombe, Bucks.). Occasionally further separations were carried out on columns $(900 \times 16 \mathrm{~mm})$ of Bio-Gel P-1o (Bio-rad Laboratories, Richmond, California) using ००o I M-Tris-acetate buffer, $\mathrm{pH}$ $8 \cdot 2$, as eluant and collecting $2.5 \mathrm{ml}$ fractions. All procedures were carried out at $\mathrm{I}^{\circ}$.

Protein concentrations were sometimes also measured by the method of Itzhaki \& Gill (1964) and sulphydryl groups by the method of Jocelyn (I962). Polyacrylamide gel electrophoresis was done by the method of Davis (1964). Amino acid analysis was performed in duplicate, using a Locarte analyser (Locarte, Emperors Gate, London), with samples hydrolysed in $6 \mathrm{M}-\mathrm{HCl}$ for $24 \mathrm{~h}$ after performic acid oxidation (Moore, 1963).

* Paper no. I: Br. J. Nutr. (1974), 32, 283.

+ Present address: Grassland Research Institute, Hurley, Maidenhead, Berks. 


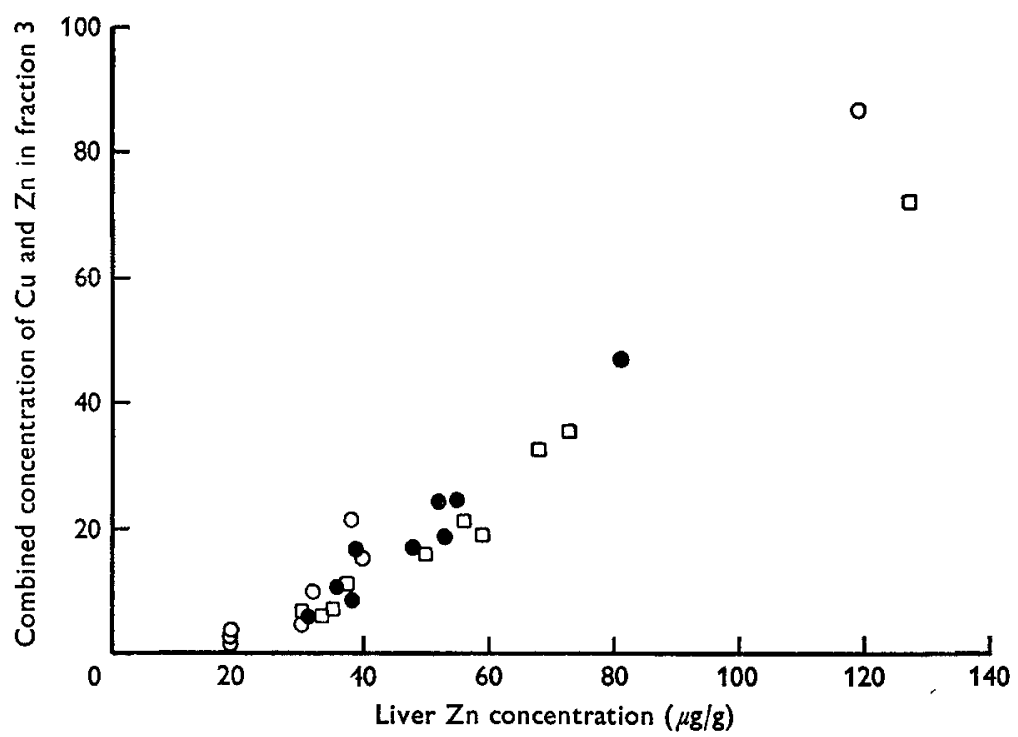

Fig. I. Relationship between liver zinc concentration and the combined concentration of copper and $\mathrm{Zn}$ present in fraction 3 ( $\mu \mathrm{g}$ metal/g fresh liver), as isolated by gel filtration on Sephadex G-75 (see p. 293). Samples were obtained from sheep $(O)$ and calves with normal ( $\square)$ and high (๑) liver $\mathrm{Cu}$ concentrations.

Addition of cadmium to liver homogenate. Two samples of a normal sheep liver homogenate were treated as follows: $(a)$ one sample was centrifuged direct at $105000 \mathrm{~g}$ for I h and a portion $(3.5 \mathrm{ml})$ of the supernatant fraction separated on Sephadex G-75 in the usual way; (b) a solution of $\mathrm{CdSO}_{4}$ was added to the other sample to give a $\mathrm{Cd}$ concentration of $4 \mu \mathrm{g} / \mathrm{ml}$. After $\mathrm{I} h$ the homogenate was centrifuged and fractionated as above.

RESULTS

\section{Concentrations of $\mathrm{Cu}$ and $\mathrm{Zn}$ in fraction 3}

There was no linear relationship between the concentrations of $\mathrm{Cu}$ in fraction 3 and in the whole liver and between those of $\mathrm{Zn}$ in fraction 3 and the liver. However, the combined concentration of $\mathrm{Cu}$ and $\mathrm{Zn}$ in this fraction was linearly related to the liver $\mathrm{Zn}$ (but not $\mathrm{Cu}$ ) concentration (Fig. I) and could be expressed by the equations:

for sheep liver: $\quad Y_{1}=0.85 x_{1}-16$ (SE of regression coefficient 0.036 ),

for calf liver: $\quad Y_{2}=0.70 x_{2}-16$ (SE of regression coefficient 0.032 ),

where $Y_{1}$ and $Y_{2}$ are the combined concentrations of $\mathrm{Cu}$ and $\mathrm{Zn}$ in fraction 3 ( $\mu \mathrm{g}$ metal/g fresh liver) and $x_{1}$ and $x_{2}$ are the liver $\mathrm{Zn}$ concentrations $(\mu \mathrm{g} / \mathrm{g})$.

These relationships applied even when $\mathrm{Cu}$ or $\mathrm{Zn}$ was absent from the fraction, as in $\mathrm{Cu}$-deficient or 'high-Cu' livers. In $\mathrm{Zn}$-deficient livers, with $\mathrm{Zn}$ contents of about I6 $\mu \mathrm{g} / \mathrm{g}, \mathrm{Cu}$ and $\mathrm{Zn}$ are absent from fraction 3 .

Large variations were found in the relative proportions of $\mathrm{Cu}$ and $\mathrm{Zn}$ in this fraction. These were dependent on the Cu: $\mathrm{Zn}$ ratio in either the whole liver or the 


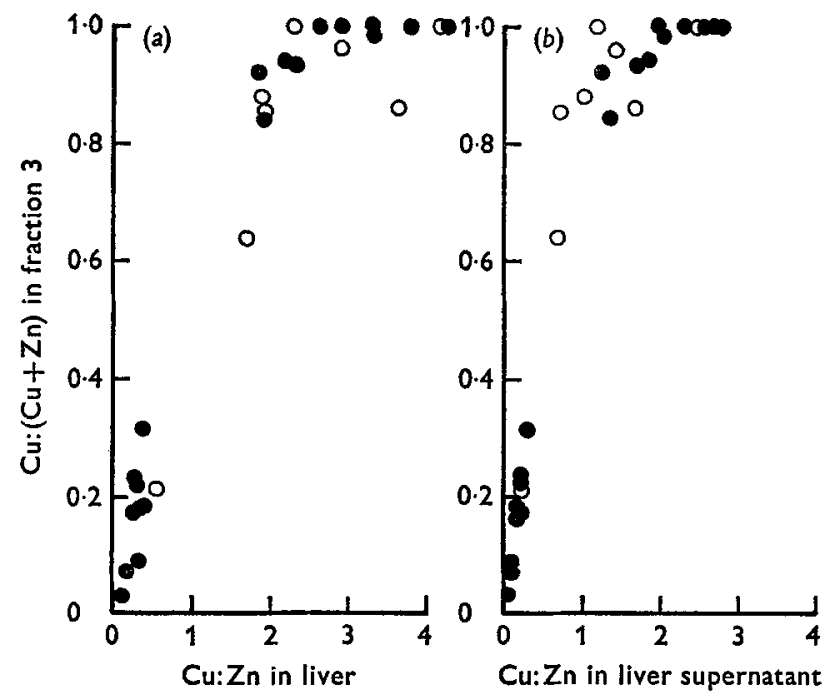

Fig. 2. Relationship between the proportion of binding sites in fraction 3 occupied by copper (i.e. $\mathrm{Cu}:(\mathrm{Cu}+$ zinc) in fraction 3$)$ and the $\mathrm{Cu}$ :zinc ratio (by weight) in (a) whole liver and $(b)$ liver supernatants. Results are shown for calf $(\bullet)$ and sheep $(O)$ livers. Fraction 3 was isolated by gel filtration on Sephadex G-75 (see p. 293).

supernatant fraction (Fig. 2). The proportion of binding sites apparently occupied in fraction 3 by $\mathrm{Cu}$ could be expressed by the equations:

$\left.\begin{array}{l}\text { (a) for sheep liver: } Y_{1}=\mathrm{I} \cdot 02-\mathrm{I} \cdot 5 e^{-1 \cdot 06 x_{1}}, \\ \text { for calf liver: } Y_{2}=\mathrm{I} \cdot 02-\mathrm{I} \cdot \mathrm{I} 2 e^{-1 \cdot 08 x_{2}},\end{array}\right\}$ (residual SD $0 \cdot 066$ ),

where $Y_{1}$ and $Y_{2}$ are $\mathrm{Cu}:(\mathrm{Cu}+\mathrm{Zn})$ in fraction 3 and $x_{1}$ and $x_{2}$ are the $\mathrm{Cu}: \mathrm{Zn}$ ratios in the whole liver;

$\left.\begin{array}{ll}\text { (b) for sheep liver: } & Y_{3}=\mathrm{I} \cdot \mathrm{OI}-\mathrm{I} \cdot 38 e^{-2 \cdot 33 x_{3}}, \\ \text { for calf liver: } & Y_{4}=\mathrm{I} \cdot \mathrm{OI}-\mathrm{I} \cdot 10 e^{-1 \cdot 59 x_{4}}\end{array}\right\}$ (residual SD 0.047),

where $Y_{3}$ and $Y_{4}$ are $\mathrm{Cu}:(\mathrm{Cu}+\mathrm{Zn})$ in fraction 3 and $x_{3}$ and $x_{4}$ are the $\mathrm{Cu}: \mathrm{Zn}$ ratios in the supernatant fraction.

It can be seen therefore that when equal amounts of $\mathrm{Cu}$ and $\mathrm{Zn}$ are present in the supernatant fraction $\left(x_{3}\right.$ and $x_{4}=\mathrm{r} \cdot 0$ ), 80 and $90 \%$ of the binding sites in fraction 3 are occupied by $\mathrm{Cu}$ in sheep and calf liver respectively. $\mathrm{A} \mathrm{Cu}: \mathrm{Zn}$ ratio of $2 \cdot 33$ and 2.07 is required in the whole liver of sheep and calves for $90 \%$ of the binding sites to be occupied by $\mathrm{Cu}$.

\section{Examination of fraction 3}

It was thought likely that fraction 3 was similar to the Cd-binding protein, metallothionein, and that it should therefore be possible to displace the $\mathrm{Cu}$ and $\mathrm{Zn}$ by $\mathrm{Cd}$. Addition of $\mathrm{CdSO}_{4}$ to a single homogenate of lamb liver to give a final concentration of $4 \mu \mathrm{g} \mathrm{Cd} / \mathrm{ml}$ caused a redistribution of the $\mathrm{Zn}$ and $\mathrm{Cu}$ in fraction 3 (Fig. 3). All $\mathrm{Zn}$ and part of the $\mathrm{Cu}$ were displaced, mainly into fraction $\mathrm{I}$, by the $\mathrm{Cd}$, about half of which occurred in fraction 3. The associated increase in the extinction at $25^{\circ} \mathrm{nm}$ in this 


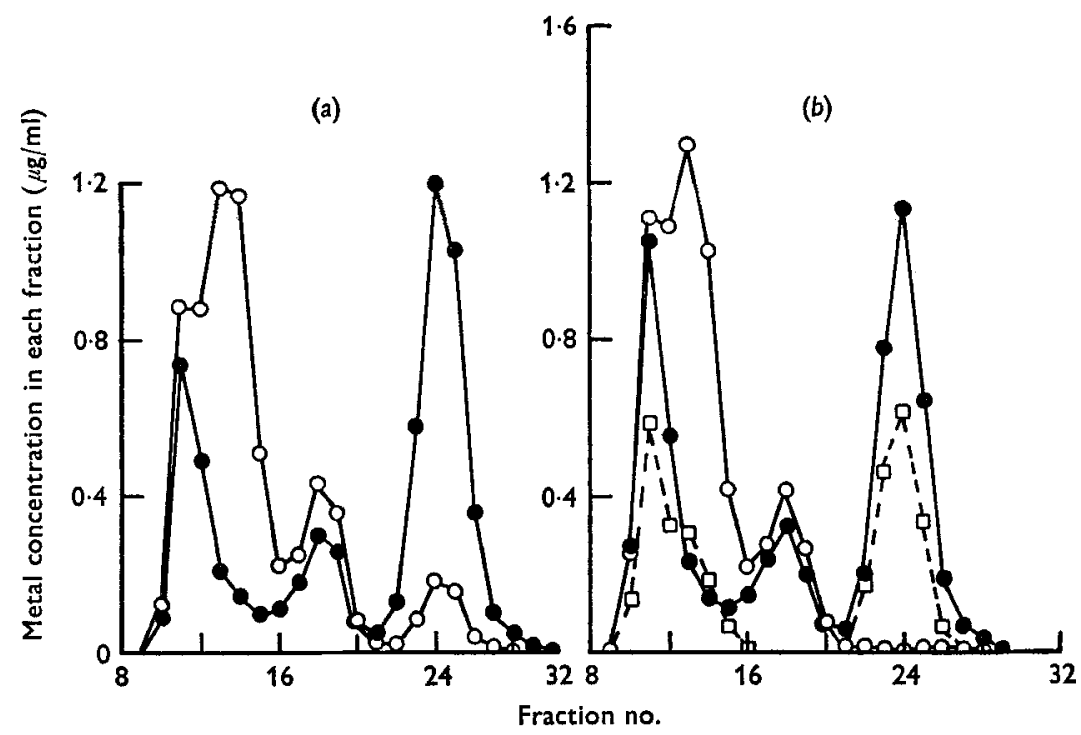

Fig. 3. Fractionation on Sephadex G-75 of supernatant fraction from (a) normal sheep liver (b) same liver after addition of $4 \mu \mathrm{g}$ cadmium $/ \mathrm{ml}$ to liver homogenate. Concentrations of zinc $(\mathrm{O})$, copper $(O)$ and $\mathrm{Cd}(\square)$ are shown; $5 \mathrm{ml}$ fractions were collected.

fraction was typical of the $\mathrm{Cd}$ mercaptide chromophore present in metallothionein (Kägi \& Vallee, 196I). The total amount of metal, on a molar basis, in the fraction was unchanged, however, as it also was after addition of excess $\mathrm{Cu}$ or $\mathrm{Zn}$ to the homogenate. This is consistent with (although not absolute proof of) the absence in the liver of apoprotein corresponding to fraction 3 and with complete saturation of all binding sites in the fraction.

\section{Gel filtration of fraction 3 on Bio-Gel P-IO}

With further separation on Bio-Gel P-Io of a sample of fraction 3, obtained from calf liver and containing mainly $\mathrm{Zn}$ with little $\mathrm{Cu}$, much of the protein was removed from the metal-containing fractions (Fig. 4). From the shape of the $\mathrm{Zn}$ peak and the greater elution volume of the $\mathrm{Cu}$ it seemed that at least three metal-containing fractions were present. Resolution of these was greatly improved by repeat gel filtration on Bio-Gel P-ro. The elution volumes of the re-run fractions (A-C) were $80,87 \cdot 5$ and $92.5 \mathrm{ml}$ and sufficiently different to support the view that the original fraction was polydisperse. Polyacrylamide gel electrophoresis at $\mathrm{pH} 8 \cdot 3$ showed that fraction $\mathrm{B}$, the main fraction, was essentially homogeneous. Fraction $\mathrm{C}$ contained two components, one with low mobility and one identical to B. Four components were present in fraction $\mathrm{A}$. The $\mathrm{Zn}: \mathrm{Cu}$ ratios in fractions $\mathrm{A}-\mathrm{C}$ were $>\mathrm{IOO},>\mathrm{IOO}$ and 4.8 respectively. All fractions had a high sulphydryl content and a molar ratio of sulphydryl groups: metal of $2 \cdot 8-3 \cdot 0$. In fraction $\mathrm{B}$ the $\mathrm{Zn}$ content of the protein was $2 \cdot 1 \%$, the protein being measured by the microbiuret method (Itzhaki \& Gill, I964). However, as appropriate standards were not available for protein estimation, this figure must be considered an approximate value only.

The amino acid composition of fraction B is shown in Table $\mathrm{I}$. Cysteine accounted 


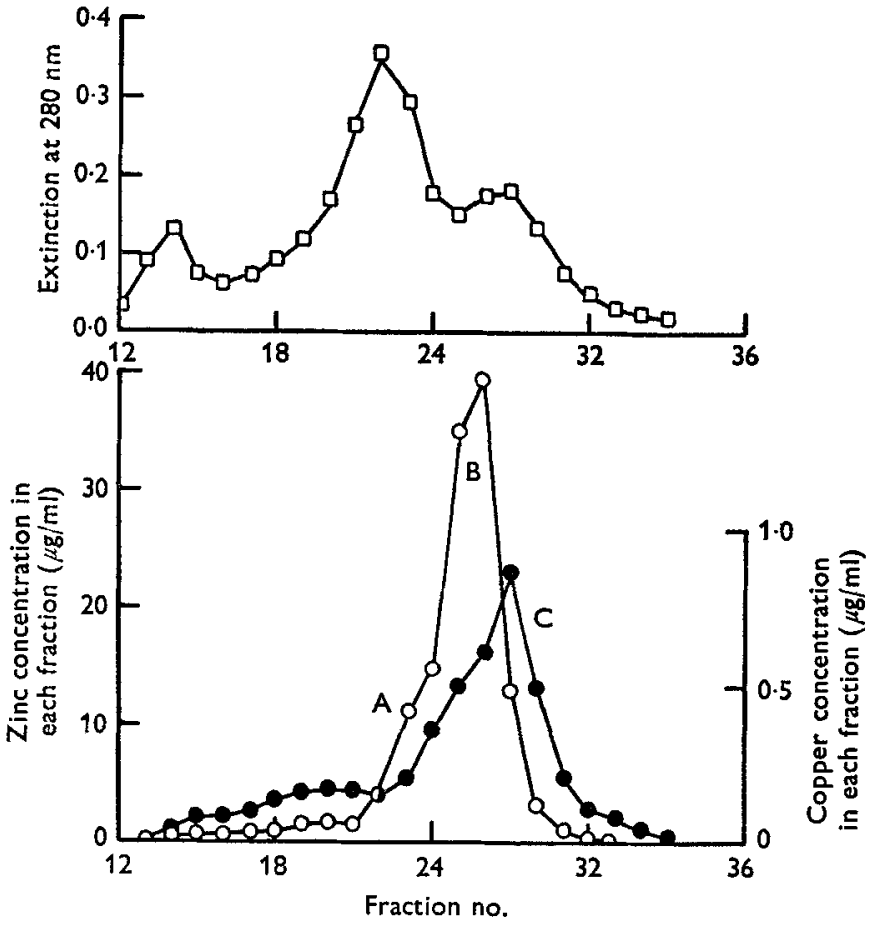

Fig. 4. Fractionation on Bio-Gel P-ro of fraction 3, obtained from calf liver by gel filtration of Sephadex G-75 (see p. 293). Extinction at $280 \mathrm{~nm}(\square)$ ), concentrations of zinc (O) and copper (-) and position of subfractions $\mathrm{A}-\mathrm{C}$ are shown.

Table I. Amino acid composition of fraction $B^{*}$ from calf liver and of horse hepatic metallothionein

Amino acid

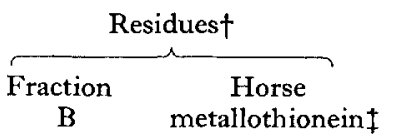

$\begin{array}{lrr}\text { Lysine } & 96 & \text { I04 } \\ \text { Histidine } & 2 & - \\ \text { Arginine } & 18 & 28 \\ \text { Aspartic acid } & 60 & 50 \\ \text { Threonine } & 39 & 41 \\ \text { Serine } & 130 & \text { I } 5 \\ \text { Glutamic acid } & 33 & 40 \\ \text { Proline } & 62 & 54 \\ \text { Glycine } & 101 & 96 \\ \text { Alanine } & 91 & 89 \\ \text { Cysteine } & 292 & 332 \\ \text { Valine } & 27 & 24 \\ \text { Methionine } & 20 & 16 \\ \text { Tsoleucine } & 9 & 9 \\ \text { Leucine } & 9 & 4 \\ \text { Phenylalanine } & 4 & -\end{array}$

* See p. 296.

+ Values are expressed per 1000 residues in the molecule. Cysteine was determined as cysteic acid. Fraction B was isolated by gel filtration on Bio-Gel P-ro, oxidized with performic acid and hydrolysed for $24 \mathrm{~h}$ in $6 \mathrm{M}-\mathrm{HCl}$.

$\ddagger$ Kägi (1970). 
for $29 \%$ of the total residues and, with methionine, accounted for all the estimated sulphydryl groups. Only trace amounts of tyrosine and phenylalanine were present, probably derived from the small proportion of contaminant protein. The composition of horse-liver metallothionein is shown for comparison (Kägi, 1970).

\section{DISCUSSION}

It is clear that fraction 3 is similar, if not identical, to metallothionein, the Cdbinding protein which may also contain $\mathrm{Zn}, \mathrm{Cu}$ and mercury, isolated from liver and kidney (Kägi \& Vallee, I960, I96ı; Kägi, I970). The amino acid composition of the principal $\mathrm{Zn}$-' metallothionein' fraction isolated from calf liver is very similar to that of the hepatic Cd-Zn proteins from other species (Table I) (Kägi, r97o; Nordberg, Nordberg, Piscator \& Vesterberg, I972; Winge \& Rajagopalan, I972). The slightly lower cysteine content may partially arise from the small proportion of contaminant protein present. The similarity of the proteins is supported by the following evidence: (a) molecular weight about 12000 , compared with about 10000 for the gel-filtration estimate of the Cd protein, $(b)$ virtual absence of extinction at $280 \mathrm{~nm}$, consistent with the absence of aromatic amino acid residues, $(c)$ increase in extinction at $250 \mathrm{~nm}$ on replacement of $\mathrm{Zn}$ and $\mathrm{Cu}$ by $\mathrm{Cd}$, which is consistent with the formation of the $\mathrm{Cd}$ mercaptide chromophore (Kägi \& Vallee, I96I), (d) high content of sulphydryl groups, (e) molar ratio, cysteine residues: metal, approximately $3,(f)$ high metal content of the protein, around $2 \%$, although this is less than some quoted values for the $\mathrm{Cd}$-protein (Kägi \& Vallee, I96I). The probable existence of at least three different 'metalloproteins' in fraction 3 with the same general properties is also consistent with the known heterogeneity of metallothionein (Kägi \& Vallee, I96r).

The question of whether the metal-free thionein is normally present in liver can only be satisfactorily resolved by development of a specific assay for it. However, as spectral studies on metallothionein (Pulido, Kägi \& Vallee, I966) suggest that thionein and $\mathrm{Cd}$ can recombine to form the native protein, it seems reasonable to suggest that the addition of $\mathrm{Cd}$ to a liver homogenate should produce an increase in the metal in the 'metallothionein'-fraction if the apoprotein is present. The failure to detect any such increase in these studies suggests therefore that the apoprotein is absent from the livers. This observation, taken with the absence of the metal-binding fraction in the livers of $\mathrm{Zn}$-deficient animals and the existence of such a close relationship between the concentrations of liver $\mathrm{Zn}$ and those of $(\mathrm{Cu}+\mathrm{Zn})$ in fraction 3 , strongly suggests that $\mathrm{Zn}$ must either be involved in the synthesis of the protein or retard its degradation. The former role is supported by recent studies on rat liver which indicate that $d e$ novo synthesis of the equivalent metal-binding fraction is induced by $\mathrm{Zn}$ and inhibited by cycloheximide (Webb, I972; Davies, Bremner \& Mills, 1973). The occurrence of this $\mathrm{Zn}$-binding fraction in male rat liver only after $\mathrm{Zn}$ injection or restriction of food intake has also been related to an increase in liver $\mathrm{Zn}$ concentration above an apparently critical level (Bremner, Davies \& Mills, I973). This suggests that production of this protein may constitute a temporary means of eliminating potentially toxic concentrations of $\mathrm{Zn}^{2+}$. 
As $\mathrm{Cu}$ has a greater affinity than $\mathrm{Zn}$ for the available binding sites, it is probable that it can compete with and displace $Z n$ from the protein, even after $Z n$ has induced its synthesis. Although the absence of any effect of hepatic $\mathrm{Cu}$ on the total metal content of fraction 3 is consistent with a lack of involvement of $\mathrm{Cu}$ in the synthesis of the protein in ruminant liver, preliminary results from rats suggest that $\mathrm{Cu}$ injection may in some circumstances induce synthesis of a protein of similar molecular weight (Bremner \& Davies, 1974). In previous reports on this $\mathrm{Cu}$ protein (Evans, Majors \& Cornatzer, 1970), it was suggested that it may have a transport function for $\mathrm{Cu}$, but no direct evidence has been produced to substantiate this. It has been postulated that apparently analogous proteins act as detoxifying agents in the metabolism of $\mathrm{Zn}$ (Webb, 1972), Cd (Nordberg et al. 1972) and $\mathrm{Hg}$ (Wisniewska, Trojanowska, Piotrowski \& Jakubowski, 1970) and this may also be the position with respect to $\mathrm{Cu}$. Alternatively, the protein may act as a non-essential store for $\mathrm{Cu}$ and $\mathrm{Zn}$. However, until the subsequent fate of $\mathrm{Cu}$ in this form has been established, this must remain unresolved.

The relationship between the concentrations of $\mathrm{Cu}$ and $\mathrm{Zn}$ and their distribution among liver proteins may be important in understanding the mutual antagonism between $\mathrm{Cu}$ and $\mathrm{Zn}$ in animals. A high dietary $\mathrm{Zn}$ intake can cause a conditioned $\mathrm{Cu}$ deficiency, which may be manifested by increased mortality, growth failure, anaemia (Hill \& Matrone, 1970) and as a reduction in the activity of cytochrome oxidase (Van Reen, I953). Conversely a Zn-deficiency syndrome can result from the use of diets with high $\mathrm{Cu}$ contents (Suttle \& Mills, 1966). Although the present results do not provide an unequivocal explanation for the interactions between these metals they do demonstrate how changes in hepatic concentration of one can affect the distribution of the other among the hepatic metalloproteins. Such changes might affect excretion or utilization of the metals or (if comparable effects exist in intestine) their absorption. Furthermore, as the thionein-like protein is obviously of key importance in controlling the distribution of $\mathrm{Cu}$ and $\mathrm{Zn}$ among hepatic proteins, liver $\mathrm{Zn}$ concentrations are seen to have an importance not previously recognized. It will be of interest to establish whether the distribution of $\mathrm{Cu}$ and $\mathrm{Zn}$ proteins in other tissues is in fact similarly controlled.

We thank Mr W. R. Hepburn for the amino acid analyses and Dr G. E. Lobley for gel electrophoretic separations.

\section{REFERENCES}

Bremner, I. \& Davies, N. T. (1974). Biochem. Soc. Trans. 2, 425.

Bremner, I., Davies, N. T. \& Mills, C. F. (1973). Biochem. Soc. Trans, r, 982.

Bremner, I. \& Marshall, R. B. (I974). Br. F. Nutr. 32, 283.

Davies, N. T., Bremner, I. \& Mills, C. F. (1973). Biochem. Soc. Trans, I, 985.

Davis, B. J. (1964). Ann. N.Y. Acad. Sci. 12x, 404.

Evans, G. W., Majors, P. F. \& Cornatzer, W. E. (I970). Biochem. biophys. Res. Commun. 40, I 42.

Hill, C. H. \& Matrone, G. (1970). Fedn Proc. Fedn Am. Socs exp. Biol. 29, 1474.

Itzhaki, R. F. \& Gill, D. M. (I 964). Analyt. Biochem. 9, 40 .

Jocelyn, P. C. (1962). Biochem. F. 85, 480 .

Kägi, J. H. R. (1970). Abstr. 8th Int. Congr. Biochem. p. I30.

Kägi, J. H. R. \& Vallee, B. L. (I960). F. biol. Chem. 235, 3460.

Kägi, J. H. R. \& Vallee, B. L. (I96I). F. biol. Chem. 236, 2435. 
Moore, S. (1 963). F. biol. Chem. 238, 235.

Nordberg, G. F., Nordberg, M., Piscator, M. \& Vesterberg, O. (1972). Biochem. F. 126, 491.

Pulido, P., Kägi, J. H. R. \& Vallee, B. L. (1966). Biochemistry, Easton 5, 768.

Suttle, N. F. \& Mills, C. F. (1966). Br. F. Nutr. 20, 135.

Van Reen, R. (1953). Archs Biochem. Biophys. 46, 337.

Webb, M. (1972). Biochem. Pharmac. 21, 275I.

Winge, D. R. \& Rajagopalan, K. V. (1972). Archs Biochem. Biophys. 153, 755.

Wisniewska, J. M., Trojanowska, B., Piotrowski, J. \& Jakubowski, M. (1970). Toxic. appl. Pharmar. I6, 754 . 